IRSTI 06.73.21

\author{
Dauliyeva G. ${ }^{1}$, Koxegenov N. ${ }^{2}$ \\ ${ }^{1}$ candidate of economic sciences, associate professor, e-mail: daulieva.galiya@kaznu.kz \\ ${ }^{2}$ master student, Almaty, e-mail: n.koxegenov@gmail.com \\ 1,2al-FarabiKazakh national university, Kazakhstan, Almaty
}

\title{
THE PROSPECT OF THE DEVELOPMENT OF CROWDFUNDING IN KAZAKHSTAN AS AN ALTERNATIVE FINANCING TOOL
}

The article discusses the new direction of financing small and medium businesses - crowdfunding. The definitions of the generic term "crowdfunding» and its particular manifestations - crowdinvesting and crowdlending are given. The example of France, one of the leaders in this area of financing in Europe, where banks and the government recognize the future importance of crowdfunding for the national economy, shows the possibilities of mutually beneficial partnership of this alternative type of financing with institutions. There is an expansion of the functions of crowdfunding platforms in order to maintain competitive advantage. Despite the marked growth of crowdfunding in the last two years and the recently shown interest of the government on the basis of such criteria as organization and size, variety of platforms, degree of national and international activity, the ratio of the banking system and the government, the conclusion is made its immaturity (underdevelopment of the organization, a negligible share of investment in the real economy, an insignificant volume of the market throughout the country, the lack of international cooperation). The stages of crowdfunding development are considered, the features of crowdlending and crowdinvesting, their differences from crowdfunding as a tool with non-financial reward are investigated. A description of the leading crowd sites in the world, as well as categories of popular projects. The article uses the methods of system and descriptive analysis, scientific abstraction, system approach. A brief analysis of the authors' works investigating this problem is given.

Key words: crowdfunding, crowdinvesting, venture investments, startups, European crowdfunding platforms, innovations.

\author{
Ааулиева Ғ.Р. ${ }^{1}$, Коксегенов Н.Ж. ${ }^{2}$ \\ 1э.ғ.к., Аоцент, e-mail: daulieva.galiya@kaznu.kz \\ ${ }^{2}$ магистрант, e-mail: n.koxegenov@gmail.com \\ 1,2әл-Фараби атындағы Қазақ ұлттық университеті, Қазақстан, Алматы қ. \\ Қаржыландырудың балама көзі ретінде \\ ҚР-ғы краудинвестингтің даму перспективалары
}

Мақалада шағын және орта кәсіпкерлікті қаржыландырудың жаңа бағыты краудфандинг туралы қарастырылады. Жалпы «краудфандинг» терминінің анықтамалары және оның ерекше көріністері - краудинвестинг және крауАленАинг келтірілген. Еуропада қаржыландырудың осы саладағы жетекші орындарының бірі, мысалы, банктер мен үкімет халық шаруашылығына арналған халық жинаудың болашақтағы маңыздылығын мойындайтын Франция үлгісі осы балама қаржыландырудың институттармен өзара тиімді серіктестік мүмкіндіктерін көрсетеді. Бәсекелестік артықшылығын сақтау үшін, көпшілік қорлар платформаларының функциялары кеңеюде. Соңғы екі жылда жинақталған қаражаттың айтарлықтай өсуіне қарамастан және соңғы уақытта үкіметтің мүАлелерін ұйымдастыру мен көлемін, платформалардың алуан түрін, ұлттық және халықаралық қызметтің дәрежесін, банктік жүйе мен үкіметтің арақатынасы сияқты критерийлер негізінде жасалды (ұйымның дамымауы, нақты экономикаға салынған инвестициялардың елеусіз үлесі, бүкіл ел бойынша рыноктың шамалы көлемі, халықаралық, ынтымақтастықтың болмауы). Краудфандингтің даму кезеңдері қарастырылады, краудлендинг 
The prospect of the development of crowdfunding in Kazakhstan as an alternative financing tool

пен краудинвестинг ерекшеліктері зерттелеАі, қаржылық емес сыйақы құралы ретінде жинақталған қаржының айырмашылығы зерттеледі. Әлемлегі жетекші крауд-алаңдардың сипаттамасы, сондай-ақ танымал жобалардың санаттары қарастырылған. Мақалада жүйелік және сипаттама талдау әдістері, ғылыми абстракция, жүйелік тәсілдер қолданы^ды. Осы мәселені зерттейтін авторлардың еңбектеріне қысқаша та^дау жаса^ды.

Түйін сөздер: краудфандинг, краудинвестинг, венчурлы инвестициялар, стартап, европалық краудфандингтік платформалар, инновациялар.

\author{
Ааулиева Г.Р. ${ }^{1}$, Коксегенов Н.Ж. ${ }^{2}$ \\ ${ }^{1}$ к.э.н., Аоцент, e-mail: daulieva.galiya@kaznu.kz \\ ${ }^{2}$ магистрант, e-mail: n.koxegenov@gmail.com \\ 1,2Казахский национальный университет имени аль-Фараби, Казахстан, г. Алматы \\ Перспективы развития краудфандинга \\ в РК как амьтернативного инструмента финансирования
}

\begin{abstract}
В статье рассматривается новое направление финансирования малого и среднего бизнеса - краудфандинг. Ааются определения обобщающего термина «краудфандинг» и его частных проявлений - краудинвестинга и краудлендинга. На примере Франции, одного из лидеров этого направления финансирования в Европе, где банки и правительство признают большое значение краудфандинга Аля национальной экономики, показаны возможности взаимовыгодного партнерства этого альтернативного вида финансирования с институтами. Отмечается расширение функций краудфандинговых платформ в целях подАержания конкурентного преимущества. Несмотря на заметный рост краудфандинга за последние два года и недавно проявленный к нему интерес правительства, на основании таких критериев, как организованность и объемы, разнообразие платформ, степень национальной и международной активности, отношение банковской системы и правительства, авторами делается вывод о его незрелости (неразвитости организации, ничтожной Аоли инвестиций в реальную экономику, незначительном объеме рынка в масштабах страны, отсутствии международного сотрудничества). Рассмотрены этапы развития краудфандинга, исследованы особенности краудлендинга и краудинвестинга их отличия от краудфандинга, как инструмента с нефинансовым вознаграждением. Аано описание лидирующих крауд-площадок в мире, а также категорий популярных проектов. В статье используются методы системного и описательного анализа, научная абстракция, системный подход. Аается краткий анализ работ авторов, исследующих эту проблему.
\end{abstract}

Кмючевые слова: краудфандинг, краудинвестинг, венчурные инвестиции, стартапы, европейские краудфандинговые платформы, инновации.

\section{Introduction}

Crowdfunding is a new method of financing various new projects, allowing individual founders of commercial, cultural or social projects to request funding from many people, often in exchange for future products or capital. Crowdfunding projects can vary widely in terms of both purpose and size, from small art projects to entrepreneurs looking for hundreds of thousands of dollars in start-up capital as an alternative to traditional venture capital investments.

For the first time, the term «crowdsourcing» was introduced by an editor and journalist Jeff Howe in 2006. Crowdsourcing - is the mobilization of people's resources through information technology to meet the challenges facing businesses, the state and society as a whole. Currently, there are various ways to use crowdsourcing, which differ in terms of subject and type of result, as well as in the category of people involved. Due to the many points of the application, in particular, due to Internet technologies, its classification in general can be made according to the sphere of life and the type of tasks to be solved (Moss, 2013).

In terms of the consideration of crowdsourcing as a tool for financing, three areas should be highlighted, which will be discussed later:

- crowdfunding - raising funds for projects without further participation in the share capital;

- crowdfunding - lending to individuals of other individuals or legal entities through special Internet sites;

- crowdinvesting - raising funds for projects with subsequent participation in the share capital (JSON.TV, 2015).

In the financial sphere, it received the name of crowdfunding as an alternative way that means investment and search mechanism of their sources. Having passed the turn of the 21 st century, the world has witnessed amazing transformations in the sphere of the usual credit and financial system connected 
with its democratization. Using the resources of the Internet, people around the world have begun to invest in ideas and projects they like to provide each other loans and loans to bypass the banking system. We consider a new crowdfunding ecosystem began to take shape very quickly. Crowdfunding is one of the new and still extremely poorly developed instruments for financing small enterprises and start-ups and has such private manifestations as crowdinvesting and crowding.

\section{Materials and methods}

The article uses the methods of system and descriptive analysis, scientific abstraction, system approach. A brief analysis of the authors' works investigating this problem is given.

System analysis is a scientific method of cognition, which is a sequence of actions to establish structural relationships between variables or constant elements of the system under study.

Descriptive method is a type of scientific method, which is a system of procedures for the collection, primary analysis and presentation of data and their characteristics. The article is preceded by an in-depth description (actually scientific) study by supplying samples and material for the deployment of further scientific procedures and methods regarding crowdfunding.

The method of scientific abstraction is a method of economic theory, which allows to exclude from the consideration of individual non-essential relationships between the subjects of the economy and to focus on the consideration of several subjects.

System approach in Economics is a methodological direction of scientific research, which consists in a comprehensive study of the economy as a whole from the standpoint of system analysis and synthesis. This article examines crowdfundingon all sides of the economic aspects, also compares with other ways of financing.

The importance of these instruments for financing as an alternative or complement to the state and institutional over time will probably increase. In a number of international and domestic documents that forecast the development of the world economy for decades to come, this direction of development of alternative instruments for financing innovations is noted as an extremely promising trend.

Materials from secondary sources are used in the article.

The realization of this came to the general public (investors, startups and regulators) after the World Bank announced that crowdfunding would cost up to 90 billion dollars between 2020 and 2025, and according to Forbes, even 2017, thus surpassing all other volumes of venture financing (Noren, 2016).

In modern studies there is a lack of unity in terminology. This, of course, makes it difficult to conduct research, especially since in different countries this phenomenon has its own characteristics and different degrees of maturity. The differences relate to the degree of organization and volume of crowdfunding, the diversity of existing platforms, the degree of national and international activity, the relationship on the part of the banking system and the government. Regulatory issues are of particular importance (Said business school, 2016).

We will give the definitions of the not yet familiar terms «crow-investing» and «crowdfunding». The term «crowdfunding» is often used as a generalizing concept that includes types of project financing by private investors, differing in the type of remuneration (lack thereof, non-financial and financial rewards) (Sanin, 2015).

«Crowdlending», or peer-to-peer lending (P2P), is called lending to individuals of other individuals or legal entities by individuals through special Internet sites. One of the largest Russian crowding areas is, for example, City of Money (2012), which specializes in lending to businesses, including small businesses and individual entrepreneurs. The platform allows operating businesses to attract funding from investors registered on it directly. The «City of Money» performs a comprehensive financial analysis of the companies represented, and the interest rate on the loan is determined by the borrower and the investor in the bidding process. In 2016, through the mediation of the site, more than 180 business projects received investments totaling 170 million rubles (Nedzveckiy, 2017:126-138).

\section{Literature review}

Despite the fact that the general model of backward driving has achieved significant success and has become a viable method of financing new enterprises, at the moment there are very few publications devoted to peer review on this topic. Schwienbacher and Larralde (2010) offered one of the first descriptions of crowdfunding, which included a brief example of studying the French musical background launch, and subsequent attempts were made to build a theoretical model of when people would choose crowdfunding (Belleflamme et al., 2012). However, several recent studies on this topic, all in the form of a working paper, tend to focus on the role of supporters and investors in the 
opposite direction. Kuppuswamy and Bayus (2013) explore how Kickstarter support varies with project success and time. Agrawal et al. (2010) used the market of musicians seeking crowdfunding weakens the geographical restrictions on fundraising, characteristic of venture capital firms.

Many researchers note that today crowdfunding is an innovation in entrepreneurial financing (Ovchinnikova, 2017, Bashirov, 2016). Crowdfunding in the Western market covers almost all aspects of the growth of human activity. In the future, a massive popularization of this trend is expected, consumer lending is expected to be replaced by crowding (Ovechkin, 2017; Zeldin, 2015)

In particular, since crowdfunding is new and potentially disruptive to traditional financing approaches, there are three areas of research that should be of interest to business scientists. First, it is important to understand how successful and unsuccessful are the successes in the opposite direction with the same basic dynamics as other forms of entrepreneurial investment, i.e., are there any projects of the foundation that signal potential quality or are some kind of less rational system? Secondly, since the characteristic feature of crowdfunding compared to other methods of financing is the elimination of geographic restrictions (Agrawal et al., 2010; Stuart, 2003a), it is important to understand what role, if any, geography continues to play in new enterprises during focus mode.

\section{Results and discussion}

Crowdfunding appeared in the United States as an independent ideology and was regulatory defined by the administration of President B. Obama in the JOBS Act (April 5, 2012), whichallowed not only qualified investors, but also ordinary citizens to engage in investmentsto encourage small businesses. From the United States, crowdfunding quickly spread to Europe, where the United Kingdom and France and Asian markets are leading today (JOBS Act, 2012).

Initially, non-commercial cultural and social projects were implemented with the help of crowdfunding, the first of which was to raise funds for the organization of a tour of the Marillion rock band in 1997 (Sanin, 2015).

After successful non-financial crowd projects, crowdfunding has penetrated into the sphere of financing start-ups and local businesses, aided by social media, which allows them to exchange information about new projects. Crowdfunding is classified by the purpose of the project (business project, creative, political, social) and by type of remuneration for sponsors (donation, non-financial remuneration, financial reward) (Bashirov, 2016: 212-219).

Among international crowdfunding platforms, the most popular platform is Kickstarter which is launched in 2009. Platform projects are monitored by US corporations, government agencies, and venture capital funds, choosing the most profitable ones for financing. Fundraising is carried out according to the «All or Nothing» model, which implies the possibility to collect only the fully collected amount. The ten most successful projects on the platform in 2015 attracted \$ 71.5 million. Mostly they were games and technological inventions(RIA News, 2016).

The second most popular platform, Indiegogo, which is launched in 2008, with a more flexible financing model, involves receiving money, even with an unmet financial goal. There are no restrictions on the type of projects. However, $70 \%$ of the leading projects for 2015 are the "Technology» category (Crowd portal, 2015).

For 8 years since the launch of Kickstarter, crowdfunding has been actively developing, and, according to 2016, $75 \%$ of Americans are aware of crowdfunding and sponsored at least one project. Thematic platforms appear on this market: «Energyfunders» is a platform designed for collective financing in the field of energy and raw materials production, Trevolta for collecting money for travel and many others. Crowdfunding in the Western market covers almost all aspects of human activity increasing growth rates. From 2014 to 2015, it grew by $167 \%$ and the amount of funds raised amounted to 16.2 billion dollars. The maximum growth was recorded in Asia - by $320 \%$, and the number of crowdfunding platforms for 2017 is more than 1,300 (Kuzmenko, 2016).

It is worth noting the advantages of crowdfunding, which led to its success:

- Democratization of the arts and culture support process and creation of additional income for the entertainment industry;

- Support for innovative solutions and startups;

- Creating a transparent and efficient financing instrument.

However, this mechanism has some disadvantages:

- Providing entrepreneurs with opportunities for pre-sales, market research, free advertising.

- Receive market information and advice from investors. Promoting the creation of perfect competition in the investment market. 
- Objective estimates of the economic indicators of the project due to direct contact with potential consumers.

- Redistribution of investments in the most promising projects during the crisis(Guseva, 2014).

- Fraud. Since there is no personal contact between the owner of the funds and the idea, the money can be used for other purposes, and the idea is stolen. Some platforms have introduced systems to detect fraudulent projects to reduce this risk.

- The discrepancy between the actual amount required and the amount claimed at the start of the project. The solution could be for the sites to use a flexible fundraising system, suggesting the possibility of adjusting the amount.

- Difficulties in making decisions about the development of the project due to geographic spread and a large number of sponsors.

- The likelihood of a conflict of interest regarding the business of the project creator and investors.

- Cash loss of sponsors in case of unsuccessful implementation of the project (Ovchinnikova, 2017).

Kickstarter film projects success rates, 2014-15

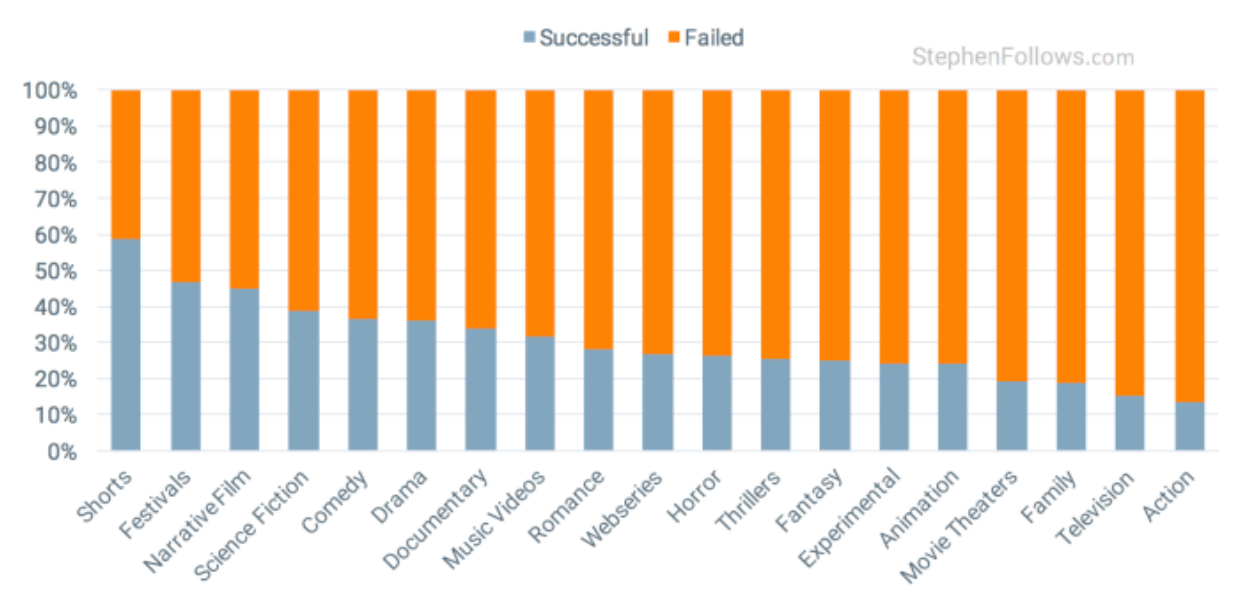

Figure 1 - Kickstarter film projects success rate, 2014-2015

Source: Mollick, 2014

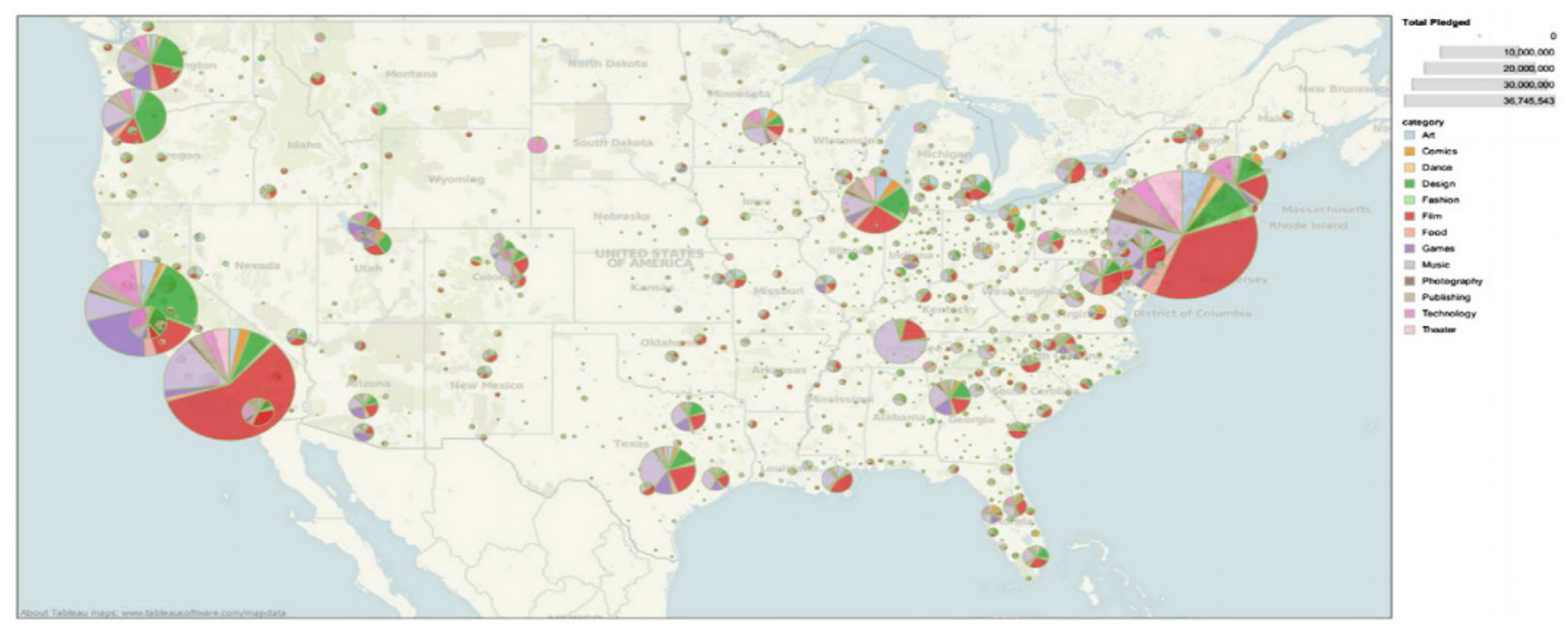

Figure 2 - Geographic distribution of projects by success and by category Source: Mollick, 2014 
In Kazakhstan crowdfundingmotionis only conceived. Largest home platform of starttime.kz for a year collected the activity from depositors 31,7 million tenge in behalf on 215 eleemosynary, social and commercial projects (Utegenova, 2018).

In 2014, five sites started: Startuper, Startticket, i6, Gostart and Asar.ainvest. They lasted less than a year. Startuper is still available on the Web, but there is not a single project on it.

Despite the collapse, the two sites were able to finance one project. The site Startticket collected 117 thousand tenge to help the shelter for stray cats, and the i6 site helped save $\$ 5,300$ for a collection of poems in the Kazakh language.

It would seem that crowdfunding in Kazakhstan withered, not having had time to develop. But it is not. On the territory of the republic there are two platforms - baribirge and Starttime. Both have successfully implemented several projects.

For one and a half month on baribirge.kz, the guys from the LampY Orchestra group collected 1.2 million tenge to record their debut album. Asathanks, theysenteachdepositorasouvenir.

The second project successfully financed was the site Inspire.KIDS, where the wishes of orphans and children from low-income families are placed. The launch of the site took 108 thousand tenge, which was collected in eight days.

In just six months, Starttime helped finance eight projects. The most notable of them are:

- Computer class for deaf children - 630,500 tenge;

- Construction of a replica of the Lotus 7 race car - 5,033,600 tenge;

- Opening of a music school for people with disabilities - 428,081 tenge.

In addition to them, they raised funds for several charitable, educational and creative projects.

The largest project, which was partially implemented with funds raised through crowdfunding, is the film «Kazakh Khanate». For donations, the organizers opened a separate site on which, taking into account sponsorship, it turned out to collect 101,296,114 tenge (Nur.kz, 2018).

We think the main reasons of that crowdfunding in Kazakhstan is not widespread as abroad are:

- lack of informing the media about domestic projects;

- difficulties for doing business at the initial stage;

- Internet infrastructure is under development;

- poor awareness of participants in this market and a low culture of authors;
- skeptical attitude of the population due to experience in the 90s with financial pyramids;

Based on existing trends, it is possible to distinguish the following possibilities of using crowdfunding:

- in 2016, the social network Facebook added a fundraising function for confirmed non-profit organizations (NPOs), and in 2017 announced that it would launch an internal crowdfunding platform. In Russia, VKontakte has opened access to money transfers, where recipients are groups, event pages and public pages. In the future, a massive popularization of this trend is expected;

- the development of crowdfunding into a global socially-creative tool because of its practicality;

- the emergence of super-platforms through the development of market leaders in geographically different directions and the collection of a variety of tools and categories of projects; The formation of niche and local competitors. With the development of giants, more and more narrowly focused services will appear. Already there are striking examples: AppStore (applications), barnraiser (agriculture), Medstartr (medicine), Experiment (science);

- development of services of collection of preorders into online shops from «Alibaba» to the shop with a meal (food crowd platforms);

- transition of platforms from crowd service in the type of permanent shops, even after completion of crowd companies;

- releasing from superfluous mediators between work/by activity and readers /spectators /fans/ maecenasesby means of subscription;

- transition of transmission and collection of facilities toward mobility;

- replacement of the consumer crediting by means of crowdlending, from a domestic technique to building multistory (Ovechkin, 2017; Zeldin, 2015).

\section{Conclusion}

Crowdfunding is a collection of funds from people who are not indifferent to a project or idea that occurs without the help of banks, the exchange or venture investors. However, crowdfunding is not something new. Since ancient times, the initiators of large-scale projects have resorted to the financial assistance of the masses to implement their ideas. Nowadays crowdfunding is conducted on different platforms which are products of Internet era. These platforms are effectively bringing together people who need each other. On the one hand, those who wish to create a business on the basis of a promising 
idea, initiators of a charitable or social project, and on the other hand, those who want to support a useful initiative free of charge or in exchange for future products of a startup.

The development of crowdsourcing as a financing instrument is due to its advantages for small businesses, which allow, in particular, to reduce costs for business. There are such basic forms as crowdfunding, crowdlending, and crownsivesting, each of which has its own niche in the financial market. In general, there is a trend towards the spread of these areas in the world. However, in Kazakhstan it is slower due to various circumstances - the lack of legislative regulation of this industry by the state, low awareness of the population about the spectrum of its use. This, in turn, indicates the need for measures to support and promote them, which further contributes to the progress of the domestic lending and financing market, and, consequently, increasing the share of small businesses, reducing corruption through the use of new types of funds and improving the economic well-being.

Crowdfunding plays an important social role, since the implementation of individual projects gives a chance to improve social life in general. The indifference of ordinary Kazakhstanis confirms that in Kazakhstan this direction has a future.

We hope soon to hear that in Kazakhstan, thanks to crowdfunding, they will make an important scientific discovery or invent a device that will change the life of humanity for the better.

Crowdfunding is a collection of funds from people who are not indifferent to a project or idea that occurs without the help of banks, the exchange or venture investors. However, crowdfunding is not something new. Since ancient times, the initiators of large-scale projects have resorted to the financial assistance of the masses to implement their ideas. Nowadays crowdfunding is conducted on different platforms which are products of Internet era. These platforms are effectively bringing together people who need each other. On the one hand, those who wish to create a business on the basis of a promising idea, initiators of a charitable or social project, and on the other hand, those who want to support a useful initiative free of charge or in exchange for future products of a startup.

The development of crowdfunding as a financing instrument is due to its advantages for small businesses, which allow, in particular, to reduce costs for business. There are such basic forms as crowdfunding, crowdlending, and crownsivesting, each of which has its own niche in the financial market. In general, there is a trend towards the spread of these areas in the world.

In Kazakhstan, crowdfunding is in its development stage. There are successful crowdfunding cases, and also active platforms like Starttime.kz and Baribirge.kz. However, in Kazakhstan the development of crowdfunding is slower than in other countries due to various circumstances - the lack of legislative regulation of this industry by the state, low awareness of the population about the spectrum of its use. This, in turn, indicates the need for measures to support and promote them, which further contributes to the progress of the domestic lending and financing market, and, consequently, increasing the share of small businesses, reducing corruption through the use of new types of funds and improving the economic well-being.

Crowdfunding plays an important social role, since the implementation of individual projects gives a chance to improve social life in general. The indifference of ordinary Kazakhstanis confirms that in Kazakhstan this direction has a future.

We hope soon to hear that in Kazakhstan, thanks to crowdfunding, they will make an important scientific discovery or invent a device that will change the life of humanity for the better.

\section{References}

Anders Noren. The best crowdfunding platforms in Europe. - 2016, https://blog.privateinvestmentsnetwork.com/category/ crowdfunding-en/

Agrawal A., Catalini C., Goldfarb A. The geography of crowdfunding // SSRN Electronic Journal. - 2010.

Belleflamme P., Lambert T., Schwienbacher A. Crowdfunding: Tapping the Right Crowd // SSRN eLibrary. - 2012.

JOBS Act. Jumpstart Our Business Startups Act. - 2012, https://www.sec.gov/spotlight/jobs-act.shtml

JSON.TV. Рынок краудфинансов в РФ: Краудфандинг, Краудинвестинг, Краудлендинг.- 2015, http://json.tv/ict_telecom analytics_view/rynok-kraudfinansov-v-rf-kraudfanding-kraudinvesting-kraudlending-20150121044017

Kuppuswamy V., Bayus B.L. Crowdfunding creative ideas: the dynamics of project backers in kickstarter // SSRN Electronic Journal. - 2013

Mollick E. The dynamics of crowdfunding: An exploratory study // Journal of business venturing. - 2014, vol. 29(1), pp. 1-16. 
Nur.kz Электронный журнал. Режим доступа: https:/www.nur.kz/1722947-kraudfanding-v-kazahstane-kak-razvivaetsa. html, 2018

Said business school. Current State of Crowdfunding in Europe. An Overview of the Crowdfunding Industry in more than 25 Countries: Trends, Volumes \& Regulations. Crowdfunding Hub. Available at: https://www.sbs.ox.ac.uk/sites/default/files/Entrepreneurship_Centre/Docs/OxEPR2/current-state-crowdfunding-europe-2016.pdf,2016

Schwienbacher A., Larralde B. Crowdfunding of small entrepreneurial ventures // SSRN Electronic Journal.-2010

Stuart T., Sorenson O. Liquidity events and the geographic distribution of entrepreneurial activity // Administrative Science. -2003. -vol. 48, p. 175

Баширов Э.Р. Краудфандинг как эффективный способ финансирования проектов // NovaInfo.Ru.- 2016. - №48, C. $214-$ 219, Режим доступа: http://novainfo.ru/article/7080

Гусева Д.Е. Краудфандинг: сущность, преимущества и риски // Современная наука: Актуальные проблемы теории и практики. - 2014. - №9, Режим доступа: http://www.vipstd.ru/nauteh/index.php/ru/---ep14-09/1278-a

Зельдин М.В. Будущее краудфандинга на 7 минут. Режим доступа: https://medium.com/crowdfunding-in-russia/в будущее краудфандинга на 7 минут -67597444912, 2015

Кузьменко В.А. Рынок краудфандинга в России: его анализ, история и перспективы / Банк знаний и база первоисточников: архив и депозитарий учебных работ и научных исследований с проверкой на уровень заимствований. - 2016, Режим доступа: http://vernsky.ru/pubs/6558/Rynok_kraudfandinga_v_Rossii_ego_analiz_istoriya_i_perspektivy?view_mode=text

Мосс А. Что такое краудсорсинг? / Портал крауд-сервисов. - 2013,http://crowdsourcing.ru/article/what_is_the_crowdsourcing

Недзвецкий Н.С. Финансовый потенциал «толпы»: российский и европейский краудфандинг // Экономика: вчера, сегодня, завтра. - 2017. - том 7. - №6А, С. 126-138.

Овечкин О. Facebook позволит запускать в соцсети сбор средств на личные цели / Rusbase. - 2017, Режим доступа: https://rb.ru/news/fb-crowdfundking/

Овчинникова А.Ю. Краудфандинг как популярный способ финансирования//Международный научно-исследовательский журнал. - 2017. -т. 1. - №02 (56), С. 37-40, Режим доступа: http://research-journal.org/wp-content/uploads/2017/02/02-3-56. pdf\#page $=37$

Портал крауд-сервисов. Краудфандинг 2015: вперед, к новым рекордам. - 2015, Режим доступа: http:/crowdsourcing.ru/ article/kraudfanding_2015_vpered_k_novym_rekordam

РИА Новости Краудфандинговые платформы в России и мире. - 2016, Режим доступа: https://ria.ru/disabled know/20160822/1474985105.html

Санин М.К. История развития краудфандинга. Классификация видов. Анализ перспектив развития и преимуществ // Научный журнал НИУ ИТМО. Серия «Экономика и экологический менеджмент». - 2015. -№ 4, С. 57-63.

Утегенова А. Журнал Форбс Казахстан. - 2018, Режим доступа: https://forbes.kz/finances/finance/kak_zarojdaetsya_ kraudfanding_v_kazahstane/

Crowdfunding's Potential for the Developing World. The World Bank. Conference version. - 2013, https://www.infodev.org/ infodev-files/wb_crowdfundingreport-v12.pdf 31 .

Current State of Crowdfunding in Europe. An Overview of the Crowdfunding Industry in more than 25 Countries: Trends, Volumes \& Regulations. CrowdfundingHub. - 2016, https://www.sbs.ox.ac.uk/sites/default/files/Entrepreneurship_Centre/Docs/ OxEPR2/currentstate-crowdfunding-europe-2016.pdf 32.

Developing World Crowdfunding. Sustainability through Crowdfunding. Alliedcrowds. Q2 Report July. - 2015.https://cdn. filestackcontent.com/Ge8GJoMTJqednEqBtb3w 33.

Raizers targets ambitious pan-european equity crowdfunding, http://cdn.crowdfundinsider.com/wp-content/uploads/2015/01/ Raizers-logo.png 37.

\section{References}

Anders Noren (2016) The best crowdfunding platforms in Europe, https://blog.privateinvestmentsnetwork.com/ category/ crowdfunding-en/

Agrawal A., Catalini C., Goldfarb A. (2010) The geography of crowdfunding. SSRN Electronic Journal.

Belleflamme P., Lambert T., Schwienbacher A. (2012) Crowdfunding: Tapping the Right Crowd. SSRN eLibrary

JOBS Act (2012) Jumpstart Our Business Startups Act, https://www.sec.gov/spotlight/jobs-act.shtml

JSON.TV (2015) Crowd finance market in the Russian Federation: Crowdfunding, Crowdinvesting, Crowdling, http://json.tv/ ict telecom analytics_view/rynok-kraudfinansov-v-rf-kraudfanding-kraudinvesting-kraudlending-20150121044017

Kuppuswamy V., Bayus B.L. (2013) Crowdfunding creative ideas: the dynamics of project backers in kickstarter. SSRN Electronic Journal

Mollick E. (2014) The dynamics of crowdfunding: An exploratory study. Journal of business venturing, vol. 29(1), pp. 1-16.

Nur.kz (2018) Electronic Journal Nur KZ, https://www.nur.kz/1722947-kraudfanding-v-kazahstane-kak-razvivaetsa.html

Said business school (2016) Current State of Crowdfunding in Europe. An Overview of the Crowdfunding Industry in more than 25 Countries: Trends, Volumes \& Regulations. Crowdfunding Hub, https://www.sbs.ox.ac.uk/sites/default/files/Entrepreneurship_Centre/Docs/OxEPR2/current-state-crowdfunding-europe-2016.pdf

Schwienbacher A., Larralde B. (2010) Crowdfunding of small entrepreneurial ventures. SSRN Electronic Journal. 
Stuart T., Sorenson O. (2003) Liquidity events and the geographic distribution of entrepreneurial activity. Administrative Science, vol. 48, p. 175

BashirovE. (2016) Kraudfanding kak effektivnyi sposob finansirovaniya proektov [Crowdfunding as an effective way to finance projects]. NovaInfo.Ru, vol. 48, pp. 214-219, http://novainfo.ru/article/7080

GusevaD. (2014) Kraudfanding: sushchnost, preimushchestvairiski [Crowdfunding: Essence, BenefitsandRisks]. Modern Science: Actual Problems of Theory and Practice, vol. 9, http://www.vipstd.ru/nauteh/index.php/ru/---ep14-09/1278-a

Zeldin M. (2015) V budushchee kraudfandinga na 7 minut [In the future of crowdfunding for 7 minutes]/ A Medium Corporation [US], https://medium.com/crowdfunding-in-russia/вбудущеекраудфандингана 7 минут -67597444912

Kuzmenko V. (2016) Rynok kraudfandinga v Rossii ego analiz istoriya i perspektivy [Crowdfunding market in Russia: its analysis, history and prospects] / Knowledge Bank and Primary Source Database: Archive and Depositary of Educational Works and Scientific Research with Credit Level Verification, http://vernsky.ru/pubs/6558/Rynok_kraudfandinga_v_Rossii_ego_analiz_ istoriya_i_perspektivy?view_mode=text

Moss Anton (2013) Chto takoe kraudsorsing [What is crowdsourcing?] / Crowd Portal, http://crowdsourcing.ru/article/what is_the_crowdsourcing

Nedzvetsky N. (2017) Finansovyi potencial «tolpy»: rossiyskiy I evropeiskiy kraudfanding [Financial potential of the «crowd»: Russian and European crowdfunding]. Economy: yesterday, today, tomorrow, vol. 7, № 6A, pp. 126-138

Ovechkin O. (2017) Facebook pozvolit zapyuskat v socseti sbor sredstv na lichnye celi [Facebook will allow to launch a fundraising for personal purposes in the social network]. Rusbase, https://rb.ru/news/fb-crowdfundking/

OvchinnikovaA. (2017) Kraudfanding kak populyarnyi sposob finansirovaniya [Crowdfunding as a popular financing method]. International Research Journal, vol. 1, № 02(56), pp. 37-40, http://research-journal.org/wp-content/uploads/2017/02/02-3-56. pdf\#page $=37$

Crowd portal (2015) Kraudfanding 2015: vpered, k nobymrekordam! [Crowd funding 2015: forward to new records!] / Crowd Portal, http://crowdsourcing.ru/article/kraudfanding_2015_vpered_k_novym_rekordam

RIA News (2016) Kraudfandingovye platform v Rossiii mire [Crowdfunding platforms in Russia and the world]. RIA News, https://ria.ru/disabled_know/20160822/1474985105.html

SaninM. (2015) Istoriya razvitiya kraudfandinga. Klassifikacia vidov. Analiz perspektiv razvitia i preimushchestv [The history of the development of crowdfunding. Classification of species. Analysis of the prospects for development and benefits]. Scientific journal NRU ITMO. Series of «Economics and Eco-management», № 4, pp. 57-63. stane/

Utegenova A. (2018) Journal Forbes Kazakhstan. https://forbes.kz/finances/finance/kak_zarojdaetsya_kraudfanding_v_kazah-

Crowdfunding's Potential for the Developing World (2013) The World Bank. Conference version, https://www.infodev.org/ infodev-files/wb_crowdfundingreport-v12.pdf 31.

Current State of Crowdfunding in Europe (2016) An Overview of the Crowdfunding Industry in more than 25 Countries: Trends, Volumes \& Regulations. Crowdfunding Hub. https://www.sbs.ox.ac.uk/sites/default/files/Entrepreneurship_Centre/Docs/ OxEPR2/currentstate-crowdfunding-europe-2016.pdf 32.

Developing World Crowdfunding (2015) Sustainability through Crowdfunding. Alliedcrowds. Q2 Report July, https://cdn. filestackcontent.com/Ge8GJoMTJqednEqBtb3w 33

Raizers targets ambitious pan-european equity crowdfunding, http://cdn.crowdfundinsider. com/wp-content/uploads/2015/01/ Raizers-logo.png 37. 